\title{
メタボリックシンドロームと腹力
}

健診受診者999名の検討

\author{
大熊 康裕 ${ }^{a}$ 青山 重雄 ${ }^{b}$ 金倉 洋一c \\ 金子 幸夫 ${ }^{\mathrm{d}}$ 佐藤 祐造 $\mathrm{e}$ \\ a＼cjkstart社会保険栗林病院健康管理センター，香川， =760-0073 高松市栗林町3-5-9 \\ あおやまクリニック，愛知， テ460-0008 名古屋市中区栄3-7-13 コスモ栄ビル $2 \mathrm{~F}$ \\ かなくらレディスクリニック, 愛知， $=450-0003$ 名古屋市中村区名駅南1-15-21 NIC 名古屋ビル $3 \mathrm{~F}$ \\ $\mathrm{d}$ 金子医院，三重，テ514-0035 津市西丸之内12-3 サナダビル $2 \mathrm{~F}$ \\ e 愛知学院大学心身科学部健康科学科, 愛知, $\overline{1} 470-0195$ 日進市岩崎町阿良池 12
}

\section{Relationship between the Metabolic Syndrome and Abdominal Tension -A Study of 999 Subjects Examined by Physical Check-up}

\author{
Yasuhiro OHKUMA $^{\mathrm{a}}$ Shigeo AOYAMA ${ }^{\mathrm{b}}$ Yoichi KANAKURA $^{\mathrm{c}}$ \\ Yukio KANEKO $^{\mathrm{d}} \quad$ Yuzo SATO $^{\mathrm{e}}$
}

a Health Care Center, Social Insurance Ritsurin Hospital, 3-5-9 Ritsurin-cho, Takamatsu City, Kagawa 760-0073, Japan

b Aoyama Clinic, Cosmo-sakae building 2 nd floor, 3-7-13 Naka-ku, Nagoya City, Aichi 460-0008, Japan

c Kanakura Lady's Clinic, NIC Nagoya building 3 rd floor, 1-15-21 Meieki-minami, Nakamura-ku, Nagoya City, Aichi 4500003, Japan

d Kaneko Clinic, 12-3 Sanada building 2 nd floor, Nishimarunouchi, Tsu City, Mie 514-0035, Japan

e Department of Health Science, Faculty of Psychological and Physical Science, Aichi Gakuin University, 12 Araike, Iwasakicho, Nisshin City, Aichi 470-0195, Japan

\begin{abstract}
Metabolic syndrome develops because of an accumulation of intra-abdominal fat. In Kampo medicine, an abdominal examination is commonly performed for the diagnosis of diseases. Thus, we examined the relationship between metabolic syndrome and abdominal tension. Our subjects were 999 people (619 males and 380 females) who underwent regular physical check-ups. Metabolic syndrome was diagnosed in 14.5\% (21.3\% of males and $3.4 \%$ of females) and the prevalence rate of subjects with metabolic and pre-metabolic syndromes was $40.8 \%$ (55.9\% of males and $16.3 \%$ of females). In addition, abdominal examinations detected $19.1 \%$ of hyperfunction, $64.6 \%$ of intermediate function, and $16.3 \%$ of hypofunction. Almost subjects with abdominal hyperfunction were classified as metabolic or pre-metabolic syndrome, and neither metabolic nor premetabolic syndrome was present in subjects with abdominal hypofunction. In conclusion, assessment of abdominal tension may become an additional valuable screening method for metabolic syndrome.

Key words : metabolic syndrome, Abdominal tension, hyperfunction, abdominal examination, screening method

\section{要旨}

メタボリックシンドロームは, 腹部内臟脂肪の蓄積が原因で発症する。漢方医学には, 腹部を診察し疾病の診断 を行う腹診がある。そこで, 健診受診者を対象に, メタボリックシンドロームと腹診による腹力との関連性につい て検討した。対象者は999名で, 男性は619名, 女性は380名であった。メタボリックシンドロームは14.5\%(男性21.3\%, 女性3.4\%）に認められ，メタボリックシンドローム予備軍も含めた有病率は40.8\%（男性55.9\%，女性16.3\%）と 高率であった。

一方，腹診では，実証19.1\%，中間証64.6\%，虚証16.3\%であった。実証は，そのほとんどがメタボリックシン ドローム, あるいはその予備軍であった。虚証の中には, メタボリックシンドローム, あるいはその予備軍は存在 しなかった。以上の結果は, 腹力の判定がメタボリックシンドロームの良好なスクリーニング法となりうることを 示唆している。

キーワード : メタボリックシンドローム, 腹力, 腹診, 実証, スクリーニング法
\end{abstract}




\section{緒言}

現代社会は，文明の進歩とともに，便利で裕福な 時代になって来た。しかしその一方で，ライフス夕 イルの変化に伴った疾病構造の変遷により, 生活習 慣病が問題となっている1)。車社会による運動不足, ファーストフードによる飽食などによって，肥満が 引き起こされる。肥満が原因で起こる疾患は多く, 特に近年注目されているメタボリックシンドローム もその一つである2)。メタボリックシンドロームは, 腹部内臓脂肪の蓄積が原因となって, 高血圧, 脂質 代謝異常, 耐糖能異常が出現し, 進行すると動脈硬 化による脳卒中や虚血性心疾患を引き起こす病態で あり，予防医学上極めて重要な位置にある。

メタボリックシンドロームに対する漢方治療の有 効性については既にいくつかの報告があり ${ }^{344)}$, 実際 の臨床の現場では実証として治療を行うことが多 ( ${ }^{5 / 6)}$ 。また, 巽らは肥満の指標である body mass in$\operatorname{dex}(\mathrm{BMI})$ と腹力は正相関することを報告してい る7)。しかし, 内蔵型肥満が原因で起こるメタボリ ックシンドロームと腹力との関連性についての検討 成績は, 未だ報告されていない。今回, 我々は健診 受診者を対象として, メタボリックシンドロームと 腹診による実証との関連性について検討し, 腹力判 定がメタボリックシンドロームの信頼しうるスク リーニング法となりうるか否かについて検討を加え た。

\section{対象と方法}

平成17年10月12日から平成18年 2 月17日までに, 社会保険栗林病院健康管理センターで健康診断を受 けた 1,110 名の中で, メタボリックシンドロームに 関する検査成績が揃っている999名（男性619名, 女 性380名）を対象とした。

医師の問診, 身体計測, 血圧測定, 採血は, すべ て健診当日に行った。また, 腹囲径の測定は, 測定 のバラツキを押さえるため筆者（大熊）ひとりで行 い，健診受診者を立位として臍レベルで測定した。 わが国のメタボリックシンドロームの診断基準に準 拠し, (1)内臟脂肪蓄積（腹囲径が男性 $85 \mathrm{~cm}$ 以上, 女性 $90 \mathrm{~cm}$ 以上: 必須項目), (2)血清脂質異常 (中性 脂肪值 $150 \mathrm{mg} / \mathrm{dl}$ 以上または HDL コレステロール值 $40 \mathrm{mg} / \mathrm{dl}$ 未満), (3)血圧高值 (最高血圧值 $130 \mathrm{mmHg}$ 以上または最低血圧值 $85 \mathrm{mmHg}$ 以上), (4)高血糖 (空腹時血糖值 $110 \mathrm{mg} / \mathrm{dl}$ 以上) の 4 項目について
表 1 対象者999名(男性619名, 女性380名) の健診結果

\begin{tabular}{l|cc}
\hline & 男性 & 女性 \\
\hline 年令 & $46 \pm 11 才$ & $47 \pm 10$ 才 \\
身長 & $169.2 \pm 6.3 \mathrm{~cm}$ & $156.4 \pm 5.6 \mathrm{~cm}$ \\
体重 & $67.7 \pm 10.8 \mathrm{~kg}$ & $54.2 \pm 8.8 \mathrm{~kg}$ \\
$\mathrm{BMI}$ & $23.6 \pm 3.2$ & $22.2 \pm 3.4$ \\
腹囲 & $86.2 \pm 8.6 \mathrm{~cm}$ & $79.7 \pm 9.8 \mathrm{~cm}$ \\
最高血圧 & $125 \pm 15 \mathrm{mmHg}$ & $118 \pm 16 \mathrm{mmHg}$ \\
最低血圧 & $77 \pm 11 \mathrm{mmHg}$ & $73 \pm 11 \mathrm{mmHg}$ \\
空腹時血糖 & $106 \pm 24 \mathrm{mg} / \mathrm{dl}$ & $96 \pm 14 \mathrm{mg} / \mathrm{dl}$ \\
中性脂肪 & $134 \pm 114 \mathrm{mg} / \mathrm{dl}$ & $80 \pm 43 \mathrm{mg} / \mathrm{dl}$ \\
HDL コレステロール & $57 \pm 15 \mathrm{mg} / \mathrm{dl}$ & $73 \pm 16 \mathrm{mg} / \mathrm{dl}$ \\
\hline
\end{tabular}

(平均 \pm S.D.)

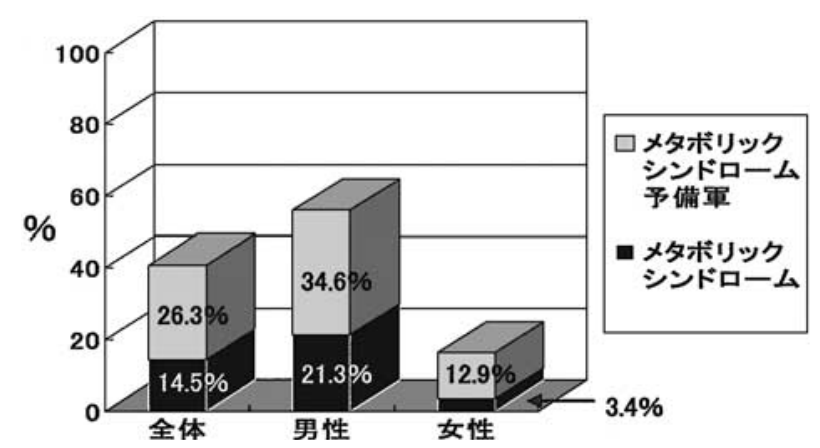

図 1 メタボリックシンドローム予備軍も含めた有病率

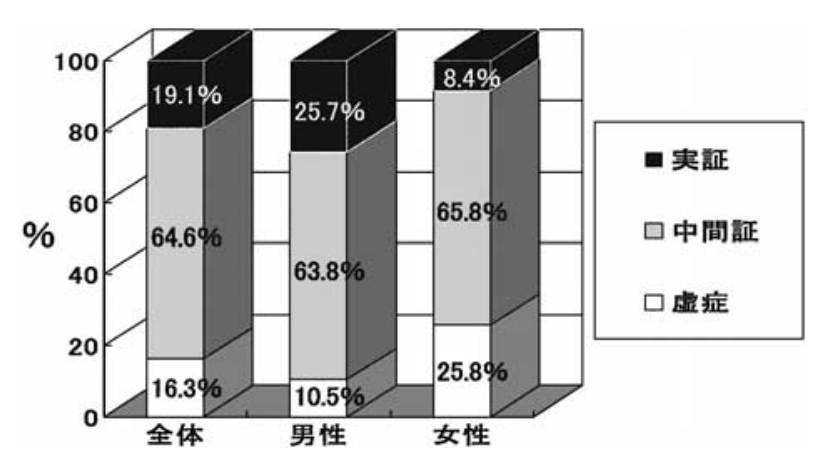

図 2 腹診による腹力判定



図 3 腹証別のメタボリックシンドロームの比率 


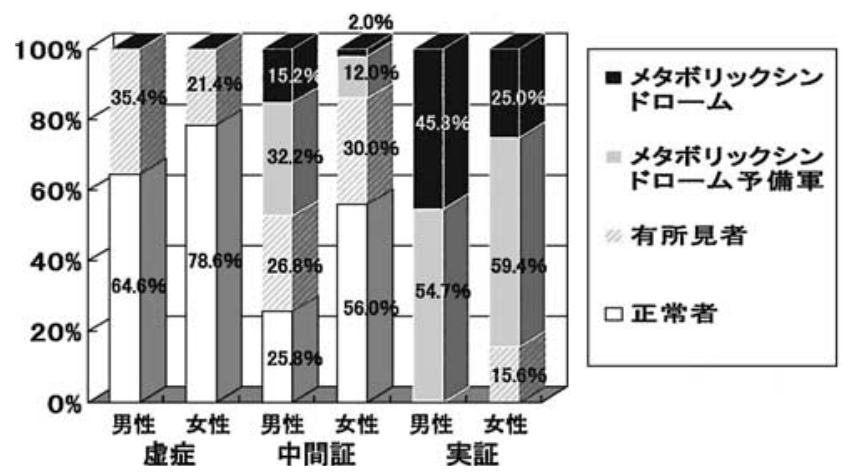

図 4 腹証別のメタボリックシンドロームの比率（男女別）

検討を加えた。健診結果より，正常者（該当項目な し), 有所見者 (内臓脂肪蓄積以外 1 項目以上が該 当), メタボリックシンドローム予備軍 (内臓脂肪 蓄積に加えて1 項目該当), メタボリックシンド ローム（内臓脂肪蓄積に加えて 2 項目以上該当）の 4 群に分けた。なお治療中の項目は該当項目として 取り扱った。

一方，健診受診者に腹診を行い，寺澤の基準に従 い，腹力により虚証（腹力 $1 \sim 2 / 5$ ), 中間証（腹力 $3 / 5)$ ， 実証（腹力 $4 \sim 5 / 5 ）$ の 3 群に分けた 8 )。なお, 腹力判定のバラッキを押さえるため, 腹診は筆者 (大熊)ひとりで行った。

\section{結果}

対象者は，999名（男性619名，女性380名）であっ た。平均年令は男性 46.4 才，女性47.0才であり， BMI, 腹囲径 (女性), 最高血圧值, 最低血圧值, 空腹時血糖值, 中性脂肪值, HDL コレステロール 值のそれぞれの平均值は基準值の範囲内であった。 しかし，腹囲径（男性）の平均値は基準值より大き かった（表 1 )。

メタボリックシンドロームは $14.5 \%$ （男性 $21.3 \%$ ， 女性3.4\%）に認められ，メタボリックシンドロー 厶予備軍も含めた有病率は $40.8 \%$ （男性 $55.9 \%$, 女 性16.3\%）であり，男性に多く認められた（図 1 )。

腹力の判定では，虚証 $16.3 \%$ （男性10.5\%，女性 25.8\%), 中間証64.6\% (男性63.8\%，女性65.8\%), 実証 $19.1 \%$ （男性 $25.7 \%$ ，女性8.4\%）であり，女 性に比べて男性で実証の割合が多かった（図 2 )。

実証群では,そのすべてに異常所見を認め, $97.4 \%$ がメタボリックシンドロームあるいはその予備軍で あった。また, 虚証群では, メタボリックシンドロー ムあるいはその予備軍は存在しなかった（图 3 )。

これを男女別にすると, 男性, 女性ともに実証に
なる程，有病率が増加した。また，同じ証で比較す ると，女性に比べて男性で正常者の割合が減少し， 有病率が増加した（図 4 ）。

\section{考察}

我が国の 3 大死因は, 悪性新生物, 心疾患, 脳血 管疾患である。その中の心疾患と脳血管疾患は循環 器疾患であり，その原因の多くは動脈硬化である。 これまで動脈硬化の危険因子としては, 高コレステ ロール血症，高血圧，喫煙などが同定されていたが， これらは個々に独立したリスク因子としての認識に 止まっていた。しかしながら，同一個人に肥満，高 血圧, 耐糖能異常, 脂質代謝異常などの危険因子が 軽度ながら集積すると, 動脈硬化性疾患の発症リス クが高まることが次第に明らかにされてきた9) 111。 また，これら危険因子の背景には内臟脂肪の蓄積や インスリン抵抗性が存在するとされており ${ }^{12)}$, 現在, この疾患単位はメタボリックシンドロームと呼ばれ ている。

本研究では, 男性の肥満者が多く BMI 25 以上の 割合は28.3\%, 腹囲径 $85 \mathrm{~cm}$ 以上が55.9\%存在し, メタボリックシンドロームは $21.3 \%$, 予備軍も含め た有病率は $40.8 \%$ と高い值を示した。これを他の調 査結果と比較すると，「平成16年 国民健康・栄養 調査結果の概要」(厚生労働省健康局総務課生活習 慣病対策室）によれば，男性肥満者の割合は年々増 加傾向にあり, BMI25以上の割合は $30.9 \%$, 腹囲径 $85 \mathrm{~cm}$ 以上が，51.9\%，メタボリックシンドローム は23.0\%, 予備軍も含めた有病率は $45.6 \%$ と, 高い 值を示しており, 本研究の結果と合致している。こ のことは，働き盛りの男性の半数以上がメタボリッ クシンドロームあるいはその予備軍であることを意 味し，現在肥満対策が重要視されている所以である。

漢方医学には「未病を治す」13) 15) という概念があ 


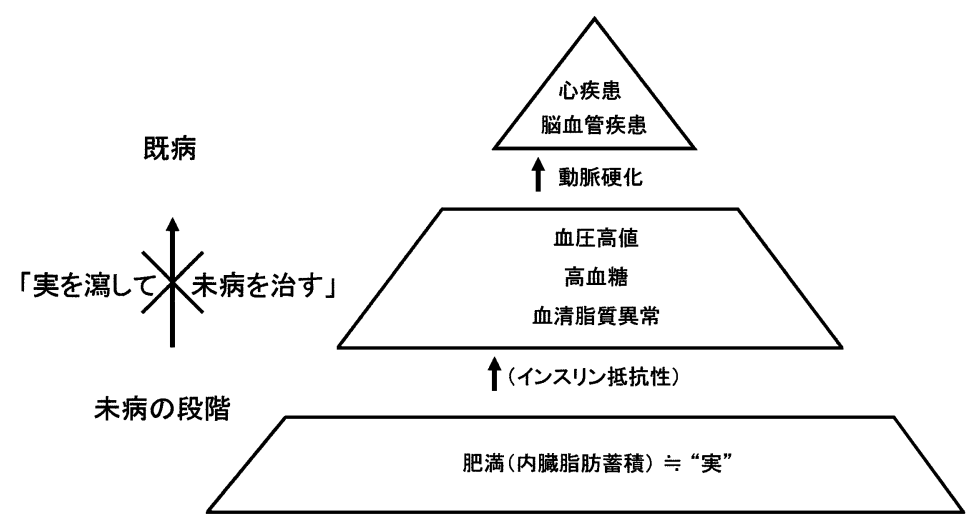

図 5 メタボリックシンドロームと漢方医学の概念

り，治療原則は「虚を補い，実を瀉す」1617)ことであ る。この定義に当てはめてメタボリックシンドロー ムを考察すると，図 $\mathbf{5}$ に示すごとく，メタボリック シンドロームは心疾患，脳血管疾患がいまだ形成さ れていない「未病」の段階にあり，その治療は過剩 に蓄積した内臓脂肪を減らす（実を瀉す）ことであ る。今回の我々の研究によれば，腹診によって実証 と判定された群は，そのほとんどがメタボリックシ ンドロームあるいはその予備群であった。このこと からすると，腹診で実証と判定された群を予め治療 することが，心疾患，脳血管障害の発症を予防する ことになることを強く示唆している。

漢方医学の腹診法は, 江戸時代に確立された我が 国独自の診察法であり ${ }^{18)}$ ，腹壁の厚薄などを診るこ とにより虚実を判定する。腹壁が薄くて弾力にそし い者は虚証が多く, 腹壁が厚くて皮下脂肪に富み弾 力のある者は実証が多いとされている ${ }^{19)}$ 。しかしな がら腹壁の厚薄だけで漢方的診断がなされるわけで はなく，他の所見や症状も含めて総合的に診断を行 う必要がある。

本研究の腹力の判定では, 虚証 $16.3 \%$, 中間証 64.6\%，実証19.1\%であったが，社会保険栗林病院 漢方外来患者 50 名では，虚証 $32.0 \%$ ，中間証 $56.0 \%$ ， 実証12.0\%であった。このことより，健診受診者と 漢方外来受診者では，証においては異なる集団であ ることが推察された。また, 長坂らの研究20) と同様 に，女性に比べて男性で実証と判定された者の比率 が多かった。さらに，中間証，実証において，男性 でメタボリックシンドロームの有病率が高かった。 この原因としては，女性に比べて男性では肥満者の 割合が多かったためと考えられた。

メタボリックシンドロームを診断する場合は，診
断基準の必須項目の 1 つとて内臟脂肪の蓄積があ る。そこで，メタボリックシンドロームを確定する 際には，内臓脂肪の蓄積を $\mathrm{CT}$ スキャンで測定する ことが望ましいが，CT スキャンによる検査は健診 時には煩雑であり，設備や経費が必要である。そこ で，最も簡便な方法として，メジャーによる腹囲径 の測定が代用されている。しかし，特に女性の場合 は，腹囲径の測定に抵抗感を持つ受診者が少なくな い。その点からすると, 腹力による虚実の判定は簡 便に実施することができた。

巽らは腹力と肥満が正相関することを報告してい る7。これをさらに進めて, 我々の研究では腹力と 内蔵型肥満との関連性について検討した。そして, 腹診で実証になるほど内蔵型肥満が原因で起こるメ タボリックシンドロームの有病率が増加することを 明らかにした。また，実証と判定されたすべての受 診者は，重症度に差はあるが，異常所見を有し，そ のほとんどの受診者がメタボリックシンドロームあ るいはその予備軍であった。このことより，腹力に よる虚実の判定がメタボリックシンドロームをスク リーニングする重要な方法になると考えられた。

\section{結論}

健診受診者を対象にメタボリックシンドロームと 腹診による腹力との関連性について検討した結果， 腹力の判定がメタボリックシンドロームの良好なス クリーニング法となりうることが示唆された。

\section{文献}

1）佐藤祐造 [編著］：生活習慣病対策および健康維 持・増進のための運動療法と運動処方, $2-8$, 文 光堂, 東京 $(2005)$

2 ）メタボリックシンドローム診断基準検討委員会： 
メタボリックシンドロームの定義と診断基準, 日 本内科学会雑誌, 94(4)，188-203 (2005)

3 ) 秋山俊治, 吉川裕之, 田中広樹, 大槻眞 : $\beta 3-$ adrenergic receptor 遺伝子変異を伴う肥満患者に対 する防風通聖散の効果，消化と吸収，21(2)，159 -161 (1998)

4) 日置智津子, 吉田俊秀: メタボリックシンドロー 厶と漢方 肥満症治療に打ける漢方の効果, 漢方 と最新治療，14(1)，13-20（2005）

5 ) 大塚敬節, 矢数道明, 清水藤太郎: 漢方診療医典 (第 6版)，142-143，南山堂，東京 (2001)

6 ) 三谷和男 : メタボリックシンドロームと漢方, 漢 方と最新治療，14(1)，43-47 (2005)

7 ) 巽武司, 土佐宽順, 長坂和彦, 嶋田豊, 伊藤隆 : 血液生化学検查所見と漢方医学的腹候の関連性に 関する検討, 日本東洋医学会雑誌, 48(2), 197203 (1997)

8 ) 寺澤捷年 : 症例から学ぶ和漢診療学, 188-198, 医学書院, 東京 (1990)

9 ) Reaven GM : Role of insulin resistance in human disease, Diabetes 37, 1595-1607 (1988)

10) Kaplan NM : The deadly quartet. Upper-body obesity, glucose intolerance, hypertriglyceridemia, and hypertension, Arch Intern Med 149：1514-1520（1989）

11) Fujioka $S$, et al : Contribution of intra-abdominal fat accumulation to the impairment of glucose and lipid metabolism in human obesity, Metabolism 36, 54-59
(1987)

12) DeFronzo RA, et al : Insulin resistance. A multifaceted syndrome responsible for NIDDM, obesity, hypertension, dyslipidemia, and atherosclerotic cardiovascular disease, Diabetes Care 14, 173-194 (1991)

13）日本漢方協会学術部：傷寒雑病論『傷寒論』『金 匱要略』(増訂版), 180-181, 東洋学術出版社, 千葉 (1993)

14）何任著, 勝田正泰監訳 : 金貴要略解説, 7-8, 東 洋学術出版社, 千葉 (2003)

15）金子幸夫：金謴要略大成（上巻），11-25，たにぐ ち書店，東京 (2003)

16）南京中医学院編, 石田秀実監訳 : 現代語訳 黄帝 内経素門 (上巻) 通評虚実論篇, 457-476, 東洋 学術出版社, 千葉 (1991)

17）南京中医学院編, 戸川芳郎監訳 : 難経解説（第81 難), 411-414, 東洋学術出版社, 千葉 (1990)

18）稲葉克文礼, 和久田寅叔虎著, 大塚敬節, 矢数道 明解題: 腹証奇覧 全, 1-3, 医道の日本社, 神 奈川 (1992)

19）大塚敬節, 矢数道明, 清水藤太郎 : 漢方診療医典 (第 6 版)，45-54，南山堂，東京（2001）

20）長坂和彦, 土佐寛順, 巽武司, 嶋田豊, 寺澤捷 年 : 胸部検査所見と漢方医学的腹候の関連性に関 する検討, 日本東洋医学会雑誌, 48(2), 185-195 (1997) 